\title{
Propagating Transparency and Accountability Through Integrated Reporting: An Empirical Insight From a Developing Country
}

\author{
Faizah Darus ${ }^{1}$, Shafawati Farhana Mohd Safihie ${ }^{2} \&$ Haslinda Yusoff ${ }^{1}$ \\ ${ }^{1}$ Accounting Research Institute, Faculty of Accountancy, Universiti Teknologi MARA, Shah Alam, Selangor, \\ Malaysia \\ ${ }^{2}$ Faculty of Accountancy, Universiti Teknologi MARA Sabah, Kota Kinabalu, Malaysia \\ Correspondence: Faizah Darus, Accounting Research Institute, Faculty of Accountancy, Universiti Teknologi MARA, \\ 40450 Shah Alam, Selangor, Malaysia.
}

Received: April 30, 2019

doi:10.5430/ijfr.v10n5p92
Accepted: May 30, 2019

Online Published: June 10, 2019

URL: https://doi.org/10.5430/ijfr.v10n5p92

\begin{abstract}
Increasing pressure from stakeholders that demands for a holistic corporate report both in terms of financial and non-financial information, has resulted in a move towards a more integrated approach in corporate reporting. The aim of this study is to examine the presence of the elements of integrated reporting and the drivers for the adoption of such reports. The influence of internal and external pressure from the perspective of agency and stakeholder theories forms the focus of this study. Content analyses of the annual reports of the top 100 companies in Malaysia for the year 2014 are examined. The results show positive relationships for the independent variables mission and vision, and risk and opportunities with the presence of the elements of integrated reporting in the annual reports. The positive relationships reveal that companies that align key strategies with the mission and vision statement and take measures to address risk and opportunities of the organization, will be more proactive in implementing integrated reporting. The findings provide empirical evidence on the progress of integrated reporting in a developing country where research to examine the effects of specific determinants on the likelihood of companies in a developing country providing integrated reports is almost non-existent.
\end{abstract}

Keywords: integrated reporting, agency theory, stakeholder theory, sustainability reporting, CSR

\section{Introduction}

Corporate reporting has grown over the last decade where non-financial reports such as corporate social responsibility (CSR) reports and sustainability reports are rapidly gaining importance as stakeholders are demanding for a more holistic approach towards the provision of information to facilitate decision-making. However, the supplemental information in the form of CSR and stand-alone sustainability reports that are currently being provided have limited decision-usefulness as this information has no direct link to the financial reporting provided due to the separation of the reports (Robertson \& Samy, 2015; Nzimande \& Padayachee 2017). Therefore, an initiative towards integrating the information in these reports has led to the development of integrated reports which will link information on economic, social, and environment provided to stakeholders. Such integrated information will allow a better flow of information to stakeholders on how an organization creates and sustains value over the short, medium, and long term.

The effort to examine the usefulness of this new approach to reporting has propelled researchers in developed economies to review the value of integrated reporting (Robertson \& Samy, 2015; Warwick \& Tuyana, 2015; De Villiers, Rinaldi, and Unerman, 2014; Lodhia, 2015; Robertson \& Samy, 2015; Frias Aceituno, Rodriguez Ariza, \& Garcia Sanchez, 2013; Frias Aceituno, Rodríguez Ariza, \& Garcia Sánchez, 2014; Jensen \& Berg, 2012). However, there is limited literature on integrated reporting in developing countries such as Malaysia and the likelihood of companies in developing countries in providing such reports (Abdalla, Siti Nabiha \& Shahbudin, 2014; Muhammad \& Zafar 2016; Okechukwu \& Hyginus 2017). Therefore, the aim of this study is to examine the presence of the elements of integrated reporting among companies in emerging economies such as Malaysia and to investigate the drivers for the early adoption of such reports by companies. In summary, this paper seeks to answer the following two research questions which are: to what extent are companies in Malaysia currently engaged in integrated reporting and secondly, the factors that may influence the voluntary adoption of integrated reporting in Malaysia. 
The internal factors such as governance structure, firm performance, and firm outlook are investigated as possible drivers for the adoption of integrated reporting. The presence of external pressures such as ownership structure and industry type is also investigated. The agency theory is used to underpin arguments to support internal pressure while the stakeholder theory is used to underpin arguments for the influence of external pressure for organizations to embark on integrated reporting.

The remainder of this paper is organized as follows. The next section provides the literature review and hypotheses generation while Section 3 elaborates on the research methodology employed in this study. Section 4 offers the findings and discussion of the results while the last part highlights the concluding remarks, limitation, and direction for future research.

\section{Review of Literature}

\subsection{Development of Integrated Reporting}

The International Integrated Reporting Committee (IIRC) was established in 2010 with a primary goal of developing a globally accepted integrated reporting framework. Robertson and Samy (2015) describe integrated reporting as: "an improvement in corporate reporting initiatives that aims to address the limitations of existing practices through the adoption of a holistic approach to the integration of social and environmental concerns directly into an organization's business and reporting environment" (Robertson \& Samy, p.194, 2015).

The role of integrated reporting is to visualize the relationship between an organization's governance, business strategy, and business model while giving a detailed analysis of the impact and relationship of both financial and non-financial opportunities, risk and performance across the value chain (IIRC, 2013; Robertson \& Samy, 2015; Mukherjee 2017). An early adopter of integrated reporting is South Africa that took steps to mandate such reports for companies listed on the Johannesburg Securities Exchange (JSE) starting from March 2010 on an "apply or explain" basis (KPMG, 2011; Lodhia, 2015; Neelam, Subhash, Mahesh, \& Anh Vu, 2015; Obiekwe, 2018). The King III Code or known as the King Code of Corporate Governance 2009 is the code that needs to be abided by the listed companies. As the King III Code itself provides a rather limited guidance on the preparation of the integrated report, it leaves most companies with their judgement and discretion regarding the format, content, and structure of the report that they wish to present. Solomon and Maroun (2012) reveal that the introduction of integrated reports for the JSE-listed companies in South Africa has caused an increase in the disclosure of social, ethical, and environmental information among the companies.

There have also been numerous studies conducted on the application of integrated reporting in developed nations (De Villiers et al. 2014; Wulf, Niemöller, \& Rentzsch, 2014; Okon \& Monday 2017; Murshed, 2018). De Villiers et al. (2014) provide evidence that there has been a shift to integrated reporting by several countries such as UK, Netherlands, Singapore, and USA reflecting that integrated reporting is gaining momentum. Wulf et al. (2014) argue that for a successful implementation of integrated reporting, not only the management board but the supervisory board also needs to ensure that the report prepared can interpret the business information, such as the strategy and business development, and are in line with integrated thinking.

As Malaysia is a developing country, the move towards implementing integrated reporting is still rather slow as this is a new area. There is extant of literature about the acceptance of integrated reporting in Malaysia. A study by PwC (2014) was the first attempt to identify the current state of disclosure of integrated reporting in Malaysia but only focusing on the disclosure aspects. The study took a sample of top 30 companies that were listed in Bursa Malaysia for the year 2013. One of their findings revealed that most of the companies in their sample have already disclosed some portions of the key elements of the integrated reporting. However, there is lack of linkages in these elements that arises from siloes reporting, rather than providing beneficial insight to the stakeholders. This is supported by Druckman, P. (2014) where the author states that integrated reporting breaks down the silo's thinking as the management adopts new ways of measuring, managing as well as disclosing information that can lead to fundamental changes both in behaviour and thinking. Furthermore, our Prime Minister, Datuk Seri Najib Razak encourages companies to be competitive by adopting the international best practices. Sime Darby Bhd one of Malaysia's largest plantation companies was the first to lead Malaysia in the production of integrated reporting in 2016. Sime Darby Bhd showed that there is definitely a greater need for companies in Malaysia to move towards a better corporate reporting. Telekom Malaysia's Chief Executive Officers and Managing Director, Tan Sri Zamzamzairani Mohd Isa also declared his support for integrated reporting and pointed out that their company had already started implementing several of the elements of integrated reporting (Hamdan, 2014; Obi \& Okekeokosisi 2018).

Datuk Johan Idris, who is the chairman of the Integrated Reporting Steering Committee of Malaysian Institute of Accountancy (MIA), also shows his support for integrated reporting and states that Integrated Reporting is a game 
changer that will allow the organization to better informed their investors so that they are able to attract sustainable capital and financing (Star, 2015). Therefore, an investigation on integrated reporting in Malaysia is timely.

\subsection{Agency Theory and Internal Pressure}

Internal factors such as the governance structure, firm performance, and the firm outlook can provide internal motivations for a company to embark on integrated reporting. In this study, the Agency theory is used to underpin arguments that internal pressures such as the governance structure, the firm performance, and the firm outlook can motivate managers as the agent to provide more holistic information by embarking on integrated reporting. This assertion is in agreement with the argument by Kaur and Lodia (2014) who pointed out that the success or failure of a firm is usually determined by the decision makers. In this study, it is argued that the management of the companies as agents has the incentive to voluntarily provide more information to convince the shareholders that they are acting in the best interest of the principal (Ali \& Haseeb, 2019). The influence of the internal forces such as corporate governance structure (board size and board professionalism), firm performance (profits and leverage) and the incorporation of forward-looking information (mission and vision statement and risks framework) will influence companies to engage in integrated reporting.

In the context of agency theory, the corporate governance of a firm is a common determinant that has always been debated. As the execution of decision making is being put in the hands of the management of the firm, some of management actions might contradict against the interest of the firm in order to fulfil their own personal interests. Therefore, an effective corporate governance structure is necessary to monitor such agency problems. Jensen and Meckling (1976) states that an effective corporate governance structure will increase the strength of the internal control that is needed in order to counter the opportunistic behaviour of management and information asymmetry problem, that will eventually lead to more disclosure of information. On the other hand, firm performance vastly affects the willingness of the firm to disclose information (Hamrouni, Miloudi, \& Benkraiem, 2015). Logically, a firm with bad financial performance will tend to disclose less information in their annual report to avoid looking bad and vice versa (Frias Aceituno et al., 2013). According to Khan, Muttakin, \& Siddiqui (2013), a more profitable firm tend to voluntarily disclose more information as they feel proud of their achievements and wanted to display a good impression on their performance.

Lastly, Eisenhardt (1989) explains organizations face the risk of uncertainties, that might affect the firm's prosperity, exposure to bankruptcy and even some intermediate outcome, and that members of the organization are only able to control a relatively small part of the future. By considering the risk bearing features and forward looking information, this will help reduce the risk of uncertainties that the organization might face in the future and allocate appropriate strategy to counter the possible risks. Menicucci (2013) states that rather than relying on historical information alone to make business judgements, forward-looking information is necessary to cope with the rapid capital market satisfying investors information needs. Prior literature suggests that the quality of information provided is better than the quantity aspect (Beretta \& Bozzolan, 2008; Zhang, 2005). Information asymmetry and uncertainties can be mitigated through the quality of corporate disclosure (Ascioglu, Hegde, Krishnan, \& McDermott, 2012; Boubaker, Hamrouni, \& Liang, 2015). Hence, having a future outlook that considers the key strategies to be incorporated into the vision and mission and considering the possible risk and opportunities, enhances the quality disclosure of information in the company's financial reporting rather than looking at the amount of meaningless overloading information being disclosed.

\subsection{Corporate Governance Structure and Integrated Reporting}

One aspect of the agency theory to counter agency problems that involve a conflict of interest between the agent and the principal is through the existence of an effective corporate governance structure. According to Rachagan (2010), having a successful implementation of an effective corporate governance will allow firms to balance the needs of managerial risk-taking and commercial abilities by setting policies and procedures that will eventually match the action of the management and the interest of the stakeholders. Effective corporate governance will ultimately increase the level of trust of the shareholders and financiers of the firm as they believe that their interest is protected (Ujunwa, 2012).

The existence of professionalism among the board members and the number of board members can influence decisions involving the adoption of new policies and procedures made by the Board. In this study, it is argued that by having professionals on the Board will encourage companies to venture into integrated reporting especially during this initial stage where a professional board will have the foresight to drive the company into adopting integrated reporting. This argument is consistent with findings by Carpenter and Westphal (2001) and Ujunwa (2012) where their studies revealed that when board members have the necessary expertise and skills specifically in finance and accounting, the 
board will be able to execute better corporate governance decisions resulting in better disclosure of information to stakeholders.

In addition to board professionalism, the size of the board has also been found to be a major determinant of an effective board (Frias Aceituno et al., 2013; Janggu, Darus, Zain, \& Sawani, 2014). The size of the board can be an influencing factor in a company's decision-making process as board size can reduce opportunistic behaviour of the board members (Amran, Lee, \& Devi, 2014). However, Bouaziz (2014) found a negative relationship between board size and the voluntary capital disclosure. In this study, consistent with the findings by Carpenter and Westphal (2001), Ujunwa (2012), Frias Aceituno et al. (2013) and Janggu et al. (2014), it is argued that professionalism and a bigger board size will provide a positive influence for the management to adopt integrated reporting.

Hence, the first and second hypotheses on the influence of corporate governance structure and integrated reporting are developed as follows:

H1: There is a positive relationship between board professionalism and the presence of the elements of integrated reporting in annual reports.

$\mathrm{H} 2$ : There is a positive relationship between board size and the presence of the elements of integrated reporting in annual reports.

\subsection{Integrated Reporting and Firm Performance}

Under the agency theory, managers in profitable companies have the tendency to disclose more information to support the continuance of their position in the company and to make the company look more favorable to stakeholders (Rouf, 2011, Albitar, 2015; Frias Aceituno et al., 2014; Haniffa \& Cooke, 2002; Ross, 1979; Sharif \& Rashid, 2014). Sharif and Rashid (2014) pointed out that the management of profitable companies will disclose more information to the public as they are proud of their accomplishments and wish to promote the impression of positive performance. This argument is consistent with the view by Albitar (2015) who rationalized that the action of managers of profitable companies in disclosing more information is to reflect on their compensation packages. Prior studies have also found a positive relationship between firm performance and the disclosure of voluntary information (Frias Aceituno et al., 2014; Haniffa \& Cooke, 2002; Khan, Muttakin, \& Siddiqui, 2013; Hamrouni, Miloudi, \& Benkraiem, 2015, Darus, Yusoff, Mohamed, \& Nejati, 2016). In this study, it is argued that profitable firms will be more willing to voluntarily adopt integrated reporting as they have the resources to embark on the new dimensions of reporting and to portray a good image.

In addition to profits, the debt structure of an organization can also influence the disclosure of information. Jensen and Meckling (1976) explain that when corporations are exposed to debts, they are more vulnerable to monitoring and being controlled. Leverage may act as a controlling device where high leverage will contribute towards the reduction of agency cost, forcing and constraining managers to act in line with the shareholder's interest (Berger \& Bonaccorsi di Patti, 2006). Therefore, these organizations may choose to disclose more information to reduce agency cost and to reassure debt holders (Lan, Wang, \& Zhang, 2013). Previous studies by various researchers revealed mixed results on the relationship between leverage and the voluntary disclosure of information (Albitar, 2015; Lan et al., 2013). Despite the mix results, it is accepted that firms with more leverage tend to lean more towards higher voluntary disclosure of information to satisfy the information needs of their creditors and to lower the cost of raising new capital (Lan et al., 2013). In this study, it is argued that firms with high leverage will be more willing to embark on integrated reporting initiatives to allow them to provide a more holistic disclosure of information to integrate their economic performance with their social and environmental initiatives.

Therefore, the third and fourth hypotheses related to firm performance and the adoption of integrated reporting are developed as follows:

H3: There is a positive relationship between profitability and the presence of the elements of integrated reporting in annual reports.

H4: There is a positive relationship between leverage and the presence of the elements of integrated reporting in annual reports.

\subsection{Integrated Reporting and Firm Outlook}

A firm outlook which incorporates forward-looking information sets the tone of where the organization is heading. Rather than merely relying on historical data to make business judgments, the disclosure of forward-looking information will allow an organization to cope with the rapid changes in the capital market which in turn will satisfy the investor's information needs (Menicucci, 2013). Companies that align key strategies with their vision and mission 
statement indicate that they have a clear future outlook of where the organization is heading and have created a roadmap of how to get there. Therefore, companies that align key strategies with their vision and mission statements would be more inclined to adopt new strategies such as the adoption of integrated reporting. Amran et al. (2014) argue that the mission and vision statement serves as the core feature for an organization's action and driver for all decision-making processes. As such, it will have a direct impact on the behaviours of the management.

It is also important for an organization to develop an effective risk management framework to protect itself against the various types of business risks. Such risks management framework will help companies to assess their risks and opportunities in their efforts to mitigate such risks. The mitigation of risks and the seeking of new opportunities are highlighted in the Integrated Reporting Framework. By assessing risks, firms will be able to take actions to mitigate the risks that will prevent them from creating value over the short, medium, and long-term (IIRC, 2013). Therefore, in this study, it is argued that companies that have a proper risk management structure will be more inclined to adopt integrated reporting in their efforts to assess and mitigate risks that will prevent them from creating value for the organization. Furthermore, the disclosure on risk management will help to reduce the agency conflict that exists between the shareholders and the management as a result of information asymmetry (Greco, 2012; Jensen \& Berg, 2012) which will, in turn, create value for the organization (Abdullah, Shukor, Mohamed, \& Ahmad, 2015).

Hence, the fifth and six hypotheses are developed as follows:

H5: There is a positive relationship between the key strategies being embedded in the vision and mission and the presence of the elements of integrated reporting in annual reports.

H6: There is a positive relationship between firms that address risk and opportunities in their annual reports and the presence of the elements of integrated reporting.

\subsection{Stakeholder Theory and External Pressure}

In addition to internal pressure, external influence can also pressure companies to embark on new ventures. The stakeholder theory is used in this study to underpin arguments on the effect of external pressure in motivating organizations to engage in integrated reporting.

Freeman (1994, p 411) defines stakeholders as, "individuals or groups that have a direct influence toward the organization's welfare, not limiting it to the financial claimants, but also involves the employees, customers, community and governmental officials".

According to Freeman (1994), the management of any firm should take into account the interest of the stakeholders before making decisions with regards to the firm's activity. This theory emphasizes on how firms respond to the pressure imposed by their stakeholders (Darus, Mad, Nejati, \& Yusoff, 2016). In the context of the initiatives to undertake integrated reporting, it is argued in this study that the pressure from stakeholders will provide the external force that will influence the organization to embark on integrated reporting. As integrated reporting is targeting the stakeholders at large, implementing such reporting practices will better address stakeholder's information needs, resulting in the ability to attract investment from the stakeholders. The presence of foreign ownership in the company and the industry type will intensify the external pressure from stakeholders which will induce companies to adopt integrated reporting.

\subsection{Ownership Structure and Integrated Reporting}

The presence of foreign ownership in an organization may exert added strain for the management to take a more holistic approach in its corporate reporting to ensure that foreign stakeholders are convinced of the value created by the organization. Stakeholders' needs may differ due to their nature, and foreign shareholders require information that will enable them to make comparisons or to benchmark against other international firms. Therefore, companies that have foreign ownership have been found to voluntarily disclose more information to allow them to effectively compete in the capital market (Huafang \& Jianguo, 2007). Larger foreign ownership will result in the ownership structure of the company being more heterogeneous which could lead towards increased conflict between the management and the shareholders (Broberg, Tagesson, \& Collin, 2010). Therefore, managers of companies with foreign ownership will respond to the stakeholder pressure by voluntarily disclosing more information to avoid potential conflicts (Huafang \& Jianguo, 2007). The pressure from foreign ownership has been found to be more prevalent among developing countries such as Malaysia (Haniffa \& Cooke, 2002). This finding can be explained by the fact that to attract foreign investments, the organizations in developing countries will be pressured to disclose more holistic information to fulfill the needs of the stakeholders. Therefore, based on the said argument, it is hypothesized that: 
H7: There is a positive relationship between foreign ownership and the presence of the elements of integrated reporting in annual reports.

\subsection{Industry Type and Integrated Reporting}

Different types of industries may face different pressures from their stakeholders to disclose particular types of information (Ghazali, 2007). Stakeholders are more sensitive towards an industry that has a direct impact on the environment in which they operate and may demand more information on how the firm handles such environmental-sensitive issues. In fact, for these types of industries, investors may be looking at the social, environmental, and ethical dimensions of the company before investing in it (Jenkins \& Yakovleva, 2006). Sumiani, Haslinda, and Lehman (2007) pointed out that the characteristics of the companies are one of the exerting pressures that lead to companies reporting environmental information. A study by Ibrahim (2014) reveals a positive relationship between industry type and voluntary segment disclosure. In this study, it is argued that there is a positive relationship between industry type and the adoption of integrated reporting due to the external pressure from stakeholders for companies in these kinds of industries to be in the forefront in integrating their economic issues with their social and environmental issues. Therefore, the following hypothesis is developed:

H8: There is a positive relationship between industry type and the presence of the elements of integrated reporting in annual reports.

\section{Research Methodology}

\subsection{The Sample}

The sample for this study comprises of the top 100 publicly-listed companies in Malaysia ranked by market capitalization. Larger companies were chosen for this study as larger companies are expected to be more likely to adopt integrated reporting voluntarily. Content analyses of the annual reports for the year 2014 were undertaken to ascertain the presence of the elements of integrated reporting in the annual reports. The year 2014 was chosen because the voluntary adoption of the Integrated Reporting Framework was introduced in Malaysia at the end of 2013. This approach is similar to a study by Michelon and Parbonetti (2012), where the reaction of companies was evaluated a year after the release of the framework. Table 1 presents the sample companies categorized by industry.

Table 1. Sample size of top 100 companies by industry

\begin{tabular}{lll}
\hline No & Industry & No. of companies \\
\hline 1 & Trading and Services & 30 \\
\hline 2 & Finance & 11 \\
\hline 3 & Industrial Product & 10 \\
\hline 4 & Plantation & 15 \\
\hline 5 & IPC & 2 \\
\hline 6 & Consumer Product & 13 \\
\hline 7 & Property & 15 \\
\hline 8 & Construction & 4 \\
\hline & Total & $\mathbf{1 0 0}$ \\
\hline
\end{tabular}

\subsection{Variables Measurement}

A disclosure index by Warwick and Tuyana (2015) with some modifications to suit the Malaysian environment was used to measure the presence of integrated reporting elements in the annual reports, which is the dependent variable for this study. A dichotomous scoring system of 0 or 1 was used for items that have limited extensiveness of disclosure, where these items were only focusing on certain actions undertaken by the companies. These items need no further clarifications. A scoring based on a ranking from 0 to 2 , on the other hand, was used to evaluate the extensiveness of disclosure for items where the quality of disclosure could be assessed. A score of 0 was given for no disclosure, a score of 1 for a general type of information disclosed and a score of 2 for extensive and specific disclosure of the information disclosed. The index contains a total of 37 items which has been categorised into the following six (6) key dimensions: 
1. Organizational overview and business model

2. Operating context

3. Strategic objectives and strategies to achieve them

\section{Governance}

\section{Performance}

\section{Assurance}

A pilot test was conducted using ten samples of companies to ensure that the checklist developed by Warwick and Tuyana (2015) is suitable in the context of Malaysian companies. The pilot test indicated that the list developed by Warwick and Tuyana (2015) could be applied, with modifications, to Malaysian companies. A disclosure score for each company was totalled but not given any specific percentage as each item of disclosure was considered equally important (Patten, 2002). The elements of an integrated reporting disclosure quality index for each dimension was constructed as follows:

$$
\sum_{j=1}^{m_{j}} \frac{d_{j}}{N}
$$

The index indicates the score for the presence of the element of integrated reporting for a company $j$, where $N$ is the maximum number of relevant items a company may disclose and $d j$ is ranked from a score of either 0 or 1 or a score ranging from 0 to 2 . The total maximum score for a company $m j$ is 57 comprising of six dimensions and 37 items. Table 2 displays the maximum score for each dimension of the elements of Integrated Reporting disclosure.

Table 2. IR Dimensions and the maximum score for IR disclosure index

\begin{tabular}{lll}
\hline No & Dimensions & Score \\
\hline 1 & Organizational overview and business model & 11 \\
\hline 2 & Operating context & 9 \\
\hline 3 & Strategic objectives and strategies to achieve them & 9 \\
\hline 4 & Governance & 9 \\
\hline 5 & Performance & 16 \\
\hline 6 & Assurance & 3 \\
\hline & Total Scores & $\mathbf{5 7}$ \\
\hline
\end{tabular}

Table 3 presents a summary of the independent variables and their measurements. Besides the eight independent variables mentioned above, this study also includes company size as the controlling variable. Company size is a common factor or determinant of most voluntary disclosure practices such as Corporate Social Responsibility (CSR) and Sustainability Reporting practices. It is measured using the logarithm of total assets (Frias Aceituno et al., 2013).

Table 3. Independent variables and their measurements

\begin{tabular}{lll}
\hline Variables & Operationalization & Measurement \\
\hline $\begin{array}{l}\text { Independent variable: } \\
\text { Agency Theory }\end{array}$ & $\begin{array}{l}\text { Board of directors that has Proportion of BOD that has Master or Phd } \\
\text { Master Degree or PhD qualifications with board size } \\
\text { qualification }\end{array}$ \\
\hline Board professionalism & The size of the board of Total number of board of directors \\
\hline Board size &
\end{tabular}




\begin{tabular}{|c|c|c|}
\hline & directors & \\
\hline Profitability & $\begin{array}{l}\text { Profits earned by the } \\
\text { company }\end{array}$ & $\begin{array}{l}\text { Return on Assets (ROA) } \\
\text { (Rouf, 2011) }\end{array}$ \\
\hline Leverage & $\begin{array}{l}\text { Amount of debts possessed by } \\
\text { the company }\end{array}$ & $\begin{array}{l}\text { Total debts over total assets } \\
\text { (Lan et al., 2013). }\end{array}$ \\
\hline Mission and Vision & $\begin{array}{l}\text { Description of the mission } \\
\text { and vision of the company. }\end{array}$ & $\begin{array}{l}0=\text { No disclosure } \\
1=\text { Below Average } \\
2=\text { Average } \\
3=\text { Above Average } \\
\text { 4=Excellent } \\
\text { (Hooks \& van Staden, 2011) }\end{array}$ \\
\hline Risk and Opportunities & $\begin{array}{l}\text { Disclosure of risk mitigation } \\
\text { activities and management } \\
\text { actions on utilising potential } \\
\text { opportunities }\end{array}$ & $\begin{array}{l}0=\text { No disclosure } \\
1=\text { Below Average } \\
2=\text { Average } \\
3=\text { Above Average } \\
\text { 4=Excellent } \\
\text { (Hooks \& van Staden, 2011) }\end{array}$ \\
\hline $\begin{array}{l}\text { Stakeholder Theory } \\
\text { Ownership structure }\end{array}$ & $\begin{array}{l}\text { Shares owned by foreign } \\
\text { shareholders }\end{array}$ & $\begin{array}{l}\text { Percentage of foreign ownership listed in the Top } 30 \\
\text { shareholdings. }\end{array}$ \\
\hline Industry type & $\begin{array}{l}\text { Industry that is directly } \\
\text { affected or affecting the } \\
\text { environment }\end{array}$ & $\begin{array}{l}0=\text { Non-environmental sensitive industry such as } \\
\text { banking/service } \\
1=\text { Environmentally sensitive industry that conducts } \\
\text { activities that involve polluting the environment or } \\
\text { massive wastage such as factories and manufacturers }\end{array}$ \\
\hline
\end{tabular}

\subsection{The Multiple Regression Model}

To understand the relationship between the independent variables and the extent of integrated reporting elements disclosed, a multiple regression analysis was conducted. The size of the company acts as the control variable.

The regression model for this study is as follows:

$$
\text { IR }=\beta_{0}+\beta_{1} \text { BPROF }+\beta_{2} \text { BSIZE }+\beta_{3} \text { PROF }+\beta_{4} \text { LEV }+\beta_{5} \text { MIS }+\beta_{6} \text { RISK }+\beta_{7} \text { OWN }+\beta_{8} \text { IND }+\beta_{9} \text { TA }+\varepsilon
$$

Where,

$\begin{array}{ll}\text { IR } & =\text { Integrated Reporting elements } \\ \beta_{0} & =\text { Indicates where the slope intercept } \\ \text { BPROF } & =\text { Board professionalism } \\ \text { BSIZE } & =\text { Total number of board of directors } \\ \text { PROF } & =\text { Profitability } \\ \text { LEV } & =\text { Leverage } \\ \text { MIS } & =\text { Mission and Vision } \\ \text { RISK } & =\text { Risks and Opportunities } \\ \text { OWN } & =\text { Ownership Structure } \\ \text { IND } & =\text { Industry types } \\ \text { TA } & =\text { Company size } \\ \text { E } & =\text { Error }\end{array}$




\section{Results and Discussion}

\subsection{Descriptive Statistics}

Table 4 presents the descriptive statistics for the dependent, independent, and control variables in this study. The results from Table 4 reveal that the mean score for the presence of the elements of IR is 38.61 , with a minimum score of 24 and a maximum score of 52. This result is a positive sign where on average the companies are disclosing more than fifty percent of the items relating to the elements of integrated reporting in their annual reports. This finding suggests that even though integrated reporting is still voluntary in nature, the elements of integrated reporting are already present in the annual reports. This development will facilitate the smooth adoption of integrated reporting by companies should such reporting be made mandatory in the future.

For the independent variables, $24.35 \%$ of the board members have a Master's Degree or a Ph.D. qualification. The board size ranges from a minimum of 5 people to a maximum of 15 members. The mean score for board size is about nine people reflecting a relatively large board. The profit of the companies ranges from a minimum return on assets of $0.11 \%$ to a maximum of $94.92 \%$ with a mean score of $9.87 \%$. These figures indicate the vast disparity in the context of return generated from the utilization of assets. The leverage variables also revealed that the minimum total debts to total assets ratio has a mean score of $21.88 \%$, ranging from a low of $1.88 \%$ to a maximum of $91.65 \%$. This result also indicates a significant variance regarding the debt structure among the companies. As for the mission and vision variable, a mean score of 1.11 shows that on average, Malaysian companies recorded low disclosures, ranging from a minimum of 0 (no disclosure) to a maximum score of 4 . For the risk and opportunities variable, the average score of 2.03 indicates that the disclosure is at an average level, ranging from a minimum score of 1 and a maximum of 4 . The foreign ownership structure for the companies on average is rather low with a mean score of $10.91 \%$. The industry type reveals that about $54 \%$ of the companies belong to environmentally-sensitive industries.

The study also conducted a descriptive statistics of the elements of Integrated Reporting by items for the year 2014. For the items with a dichotomous scoring of 0 or 1 (in italics) where the focus is on whether the companies had taken action, the highest mean score relates to all items under the Assurance dimension and also for the Operating context dimension specifically for items Social and Environmental. The findings suggest that the companies are concerned about compliance with regulatory requirements and the enhancement of the credibility of information provided to stakeholders. The issues relating to social and environmental matters are also important. The next highest disclosure of information is for the item Actions taken to monitor strategic direction and Commercial items (99\%) under the Governance and Operating Context dimensions, respectively. The results suggest that the companies are disclosing information about their products to stakeholders. In terms of governance, the companies are concerned that they remain focused on achieving the strategies they had set out earlier and are taking steps to monitor the strategic direction of possible internal or external changes that may require the re-alignment of their strategic direction. The item Management Expectations under the Performance dimension is the third highest disclosed item for this group (97\%) suggesting that the management is transparent about its expectation in generating profits for the organization. The least disclosed item for this group relates to the item Reporting boundary under the Organizational Overview and Business Model dimension (0\%). Therefore, even though the report covers information relating to the company and other businesses that the organization exercises control, or has a significant influence on financial and operating policies and practices, no statement is found in the annual reports stating clearly the boundary to which the report relates. It is important that an identification of the reporting boundary is made to ensure transparency of all information reported.

For the items that were evaluated based on the extensiveness of disclosure using a ranking from 0 to 2 , the results revealed that the disclosure items Ownership and operating structure and Key quantitative information both under the Organizational overview and business model dimension had a $100 \%$ disclosure. The Leadership structure, diversity and skill set of those charged with governance item under the Governance dimension also had a $100 \%$ disclosure. These are the top three most extensively disclosed items. The least disclosed information for this group of items relates to the item Oversight over the IR process under the Governance dimension (3\% disclosure). However, overall, the extensiveness of disclosure for all the items investigated is good as most items scored more than $50 \%$ disclosure of the related information.

Table 4. Descriptive analysis of dependent, independent, and control variable

\begin{tabular}{lllll}
\hline Variables & Min & Max & Mean & Std. Dev. \\
\hline IR & 24 & 52 & 38.61 & 6.698 \\
\hline
\end{tabular}




\begin{tabular}{lllll}
\hline Board professionalism & 0.00 & 73.33 & 24.35 & 16.91 \\
\hline Board size & 5 & 15 & 9.17 & 2.10 \\
\hline Profit & 0.11 & 94.92 & 9.87 & 12.58 \\
\hline Leverage & 1.88 & 91.65 & 21.88 & 25.05 \\
\hline Mission and Vision & 0 & 4 & 1.11 & 1.12 \\
\hline Risk and Opportunities & 1 & 4 & 2.03 & 0.81 \\
\hline Ownership Structure & 0 & 58 & 10.91 & 11.08 \\
\hline Industry types & 0 & 1 & 0.54 & 0.50 \\
\hline Company size & 345,507 & $640,300,000$ & $35,048,235$ & $87,894,500$ \\
\hline
\end{tabular}

Table 5 presents the correlation analysis for this study. The results from Table 5 reveals that all the independent variables and control variable have a positive correlation with the elements of Integrated Reporting. The results show that board professionalism has a low significant positive correlation with the elements of Integrated Reporting $(\mathrm{r}=0.275)$ at $1 \%$ significance level. This suggests that the professionalism of board members has a positive relationship with decisions to voluntarily adopt Integrated Reporting. This could be because directors with professional qualifications are more receptive towards change and are willing to venture into integrated reporting. The board size also has a low significant positive correlation ( $\mathrm{r}=0.227)$. This finding is consistent with findings by Frias Aceituno et al. (2013) who found a positive correlation at $1 \%$ significance level between board size and the production of Integrated Reporting. Therefore, to some extent board size does facilitate the adoption of integrated reporting since a bigger board comes with more expertise and capabilities.

However, the performance variables, profit and leverage ratio, showed low correlation, $(r=0.075$ and 0.0390 respectively but not significant). The mission and vision variables showed a significant positive relationship at $1 \%$ level of confidence $(\mathrm{r}=0.627)$, which indicates a moderate correlation with the dependent variable. This indicates that taking into consideration the importance of mission and vision will increase the disclosure of the elements of Integrated Reporting.

The independent variable, risk and opportunities, also showed a positive significant relationship with the disclosure of Integrated Reporting elements at $1 \%$ level of confidence with moderate correlation, where $r=0.526$. This indicates that increased risk mitigation and consideration of strategies to grab potential opportunities is associated with increased disclosure of Integrated Reporting elements. Such findings are similar to Abdullah et al. (2015). The ownership structure and industry types however, have no significant relationship with the dependent variable with $\mathrm{r}$ showing a value of 0.107 and 0.139 , respectively.

Table 5. Results of Pearson correlation test for independent variables and control variables on IR elements disclosure

$$
\text { BPROF BSIZE PROF LEV MIS RISK OWN IND TA }
$$

\begin{tabular}{llllll}
\hline BPROF & & & \\
BSIZE & $.234^{*}$ & & & \\
\hline PROF & .075 & -.172 & & & \\
\hline LEV & .102 & -.004 & $-.207^{*}$ & & \\
\hline MIS & $.280^{* *}$ & $.280^{* *}$ & -.068 & .064 & \\
\hline RISK & $.224^{*}$ & .116 & .066 & .142 & $.476^{* *}$ \\
\hline
\end{tabular}




\begin{tabular}{llllllllll}
\hline OWN & $.344^{* *}$ & .091 & $.265^{* *}$ & .155 & .069 & .084 & & \\
\hline IND & -.073 & -.021 & .173 & $-.422^{* *}$ & .019 & .109 & -.173 & \\
\hline TA & $.202^{*}$ & .158 & $-.214^{*}$ & $.661^{* *}$ & $.261^{* *}$ & $.309^{* *}$ & $.256^{*}$ & $-.241^{*}$ & \\
\hline IR & $.275^{* *}$ & $.227^{*}$ & .075 & .039 & $.627^{* *}$ & $.526^{* *}$ & .107 & .139 & .271
\end{tabular}

Note: BPROF: Board professionalism, BSIZE: Board size, PROF: Profitability, LEV: Leverage, MIS: Mission and Vision, RISK: Risk and opportunities, OWN: Ownership Structure, IND: Industry Types, TA: Company size, IR: Integrated Report

**. Correlation is significant at 0.01 level (2-tailed)

*. Correlation is significant at 0.05 level (2-tailed)

Durbin-Watson statistics was used to test the independence of residuals in this study. As seen in Table 6, the value of Durbin-Watson for disclosure of Integrated Reporting elements is 1.941, which indicates it is approximately equivalent to 2. This reveals that there are no serial correlations between all of the variables. One important assumption of linear regression model is that the error term have some homogeneous variance. Basically, it showed us the presence of equal variance of the residuals upon the predicted variable scores. Whenever the assumptions is violated, one can assume that there is a presence of heteroscedasticity. Residual plot was examined to ensure that the assumptions of heteroscedasticity was not violated. The results are presented in the Appendices. As can be seen in the Appendices, the scatter plot showed that the residuals are distributed almost in a form of rectangular shape where the scores were mostly concentrated in the centre, along point 0 . Therefore, it can be assumed that heteroscedasticity was not present.

Table 6. Durbin-Watson results

\begin{tabular}{ll}
\hline Dependent Variables & Durbin-Watson \\
\hline Disclosures of Integrated Reporting Elements & 1.941 \\
\hline
\end{tabular}

Table 7 presents the results of the multiple regression analysis. No collinearity issue was observed, as the VIF values for all independent variables are below 5. The F-statistic for the model is 10.227 and is significant while the adjusted $\mathrm{R}^{2}$ coefficient is 0.456 . The results indicate that two of the variables, Mission and vision and Risk and opportunities are significant predictors for the presence of the elements of IR at 99\% level of confidence, therefore, supporting H5 and H6.

Table 7. Regression results for independent variables and integrated reporting elements disclosure

\begin{tabular}{llllll}
\hline Variables & Beta & T & Sig & Tolerance & VIF \\
\hline Constant & 11.81 & 1.345 & .182 & & \\
\hline BPROF & .016 & .183 & .855 & .716 & 1.397 \\
\hline BSIZE & .038 & .473 & .637 & .873 & 1.145 \\
\hline PROF & .214 & 1.924 & .058 & .444 & 2.255 \\
\hline LEV & .062 & .631 & .530 & .566 & 1.768 \\
\hline MIS & .462 & 5.085 & $.000^{* *}$ & .666 & 1.501 \\
\hline RISK & .276 & 3.083 & $.003^{* *}$ & .688 & 1.454 \\
\hline OWN & .007 & .085 & .933 & .817 & 1.225 \\
\hline IND & .110 & 1.303 & .196 & .777 & 1.287 \\
\hline TA & .183 & 1.555 & .123 & .397 & 2.521 \\
\hline
\end{tabular}




\begin{tabular}{ll}
\hline R square & $=.506$ \\
\hline Adjusted $\mathrm{R}^{2}$ & $=.456$ \\
\hline $\mathrm{F}$ & $=10.227$ \\
\hline Sig. & $=.000$
\end{tabular}

Coefficient for each variable is shown with $\mathrm{t}-$ statistics in parentheses

** Significant at $1 \%$ level (1-tailed test)

*Significant at 5\% level (1-tailed test)

The mission and vision statement sets the fundamental value of the organizations and will map out the direction of the companies despite changes in their operating structure or changes in the key personnel. Key strategies that are proposed by the companies would normally be in agreement with the mission and vision statement to achieve the set objectives. H5 predicted that organizations that linked key strategies with their mission and vision statement were more inclined towards adopting integrated reporting. The significant relationship between the variable mission and vision and the elements of IR suggests that companies that always align their key strategies with their mission and vision statement are more likely to adjust to new developments and would voluntarily adopt new measures to be in agreement with global changes. This finding is consistent with the findings by Amran et al. (2014) where the study revealed that incorporating CSR values into the vision and mission statements of the company, improved the sustainability reporting quality. Therefore, H5 is accepted.

H6 hypothesized that there is a positive relationship between firms that address risk and opportunities in their annual reports and the presence of the elements of Integrated Reporting. The significant association between the variable Risks and opportunities and the elements of IR imply that companies that are concerned about understanding the risks and capitalizing on their opportunities seem to have the elements of IR in their annual reports. Such initiatives will create value for the organizations. This finding is consistent with the findings of Abdullah et al. (2015) who argued that increasing the disclosure on risk mitigations will enhance a firm's value. Such measures will also increase the investors' confidence about the future performance of the business and improve the company's prospects (Knechel \& Deumes, 2008). Therefore, H6 is accepted. The other variables involving internal pressure i.e., governance structure and firm performance are not significant in inducing companies to adopt integrated reporting. Therefore, H1, H2, H3, and H4 are rejected. These findings are consistent with a study by Haniffa and Cooke (2002) who found no significant relationship between the education levels of the board of directors and the extent of the voluntary information disclosure. Albitar (2015) and Aksu and Kosedag (2006) also found no significant relationship between leverage and the voluntary disclosure of information. However, the findings contradict with that of Frias Aceituno et al. (2013) who found a positive relationship between board size and the production of integrated report. The findings also contradict previous studies that found positive relationships between profitability and the disclosure of voluntary information (Frias Aceituno et al., 2014; Haniffa \& Cooke, 2002; Khan, Muttakin, \& Siddiqui, 2013; Hamrouni, Miloudi, \& Benkraiem, 2015, Darus, et al., 2016).

The external pressure in the form of foreign ownership and industry type does not seem to influence companies to undertake the early adoption of integrated reporting. The results from Table 7 show that there is no significant relationship between foreign ownership structure and industry type with the adoption of integrated reporting. This finding contradicts that of Huafang and Jianguo (2007) who found positive results between foreign ownership structure and the voluntary disclosure of information to avoid potential conflicts (Huafang \& Jianguo, 2007). However, the finding is consistent with the results by Frias Aceituno et al. (2014) who found no significant relationship between industry type and the likelihood of the production of integrated reports. Therefore, $\mathrm{H} 8$ is rejected.

\section{Conclusions}

Integrated reporting is seen as the way forward for corporate reporting because such reporting will provide clearer links between the information presented in the annual reports. Such reports will also improve the transparency and accountability of the information to the stakeholders. There have been various prior studies on integrated reporting in the developed economies; however, there is limited literature on integrated reporting in developing countries such as Malaysia where such reporting is still voluntary in nature. Therefore, the aim of this study was to examine the presence of the elements of integrated reporting in the annual reports of the top 100 public-listed companies in Malaysia and the drivers for the early adoption of such reports. Content analyses of the annual reports for the year 2014 were undertaken to ascertain the presence of the elements of integrated reporting in the annual reports. 
The overall quality of the extensiveness of information disclosed showed a positive trend as most companies disclosed more than fifty percent of the items investigated. The findings suggest that even though integrated reporting is still voluntary in nature, Malaysian companies are already taking steps to disclose some of the elements of integrated reporting in their annual reports. This is consistent with the findings by $\mathrm{PwC}$ (2014) where mainly most of the Malaysian companies were already disclosing at least a few of the key elements of the Integrated Reporting Framework but there were no linkages being made between the elements that were disclosed (Ahmed, Abdul Majid, Zin, Phulpoto \& Umrani, 2015). These initiatives however, will facilitate the smooth adoption of integrated reporting in Malaysia, especially among the larger companies. The companies were also found to be concerned about the credibility of the information disclosed suggesting the presence of greater concern for the reliability of the information provided to stakeholders. This can be seen in the findings where among all of the Integrated Reporting elements, the Assurance dimension (mandatory audit, review, and internal audit) had the highest disclosure score suggesting that stakeholders require all of the reporting needs to be audited and reviewed by the relevant authorities to ensure the delivery of reliable informations.

The link of key strategies with the mission and vision statement and firms that address risk and opportunities were found to have significant relationships with the presence of the elements of Integrated Reporting. External pressure from foreign shareholders and industry type, however, did not seem to influence the early adoption of integrated reporting.

The findings from this study will benefit stakeholders to understand the forms of pressure that will induce companies to adopt integrated reporting in a developing country such as Malaysia. Hence, the findings may provide some meaningful insights on the forms of pressure that will generate effective actions. Such findings can also complement initiatives from regulatory bodies and policymakers to develop policies when decisions are made to make such reports mandatory in the future.

However, this research is limited to only one year of study. Future research can undertake a longitudinal study to examine the trend of the information disclosed. This will allow for a better interpretation of results. Future studies could also undertake research to cover periods before and after the introduction of the integrated reporting framework after such reports are made mandatory. Interviews with the management of these companies could also be incorporated to better understand the motivation and challenges of adopting integrated reporting. Despite these limitations, the findings from this study have contributed to filling the gaps in the literature on integrated reporting in a developing country such as Malaysia.

\section{Acknowledgements}

The researchers would like to thank the Accounting Research Institute (ARI) and the Ministry of Higher Education Malaysia for the research grant received.

\section{References}

Abdalla, Y. A., Siti-Nabiha, A., \& Shahbudin, A. S. (2014). Social and Environmental Accounting Research: The Way Forward. International Journal of Economics \& Management, 8(2), 365-383.

Abdullah, M., Shukor, Z. A., Mohamed, Z. M., \& Ahmad, A. (2015). Risk management disclosure: A study on the effect of voluntary risk management disclosure toward firm value. Journal of Applied Accounting Research, 16(3), 400-432. https://doi.org/10.1108/JAAR-10-2014-0106

Ahmed, U., Abdul Majid, A., Mohd Zin, M. L., Phulpoto, W., \& Umrani, W. A. (2015). Role and impact of reward and accountability on training transfer. Business and Economics Journal, 7(1), 1-6.

Aksu, M., \& Kosedag, A. (2006). Transparency and Disclosure Scores and their Determinants in the Istanbul Stock Exchange. Corporate Governance: An International Review, 14(4), 277-296. https://doi.org/10.1111/j.1467-8683.2006.00507.x

Albitar, K. (2015). Firm Characteristics, Governance Attributes and Corporate Voluntary Disclosure: A Study of Jordanian Listed Companies. International Business Research, 8(3), 1-10. https://doi.org/10.5539/ibr.v8n3p1

Ali, A., \& Haseeb, M. (2019). Radio frequency identification (RFID) technology as a strategic tool towards higher performance of supply chain operations in textile and apparel industry of Malaysia. Uncertain Supply Chain Management, 7(2), 215-226. https://doi.org/10.5267/j.uscm.2018.10.004

Amran, A., Lee, S. P., \& Devi, S. S. (2014). The Influence of Governance Structure and Strategic Corporate Social Responsibility Toward Sustainability Reporting Quality. Business Strategy and the Environment, 23(4), 217-235. https://doi.org/10.1002/bse.1767 
Ascioglu, A., Hegde, S. P., Krishnan, G. V., \& McDermott, J. B. (2012). Earnings management and market liquidity. Review of Quantitative Finance and Accounting, 38(2), 257-274. https://doi.org/10.1007/s11156-010-0225-9

Beretta, S., \& Bozzolan, S. (2008). Quality versus Quantity: The Case of Forward-Looking Disclosure. Journal of Accounting, Auditing \& Finance, 23(3), 333. https://doi.org/10.1177/0148558X0802300304

Berger, A. N., \& Bonaccorsi di Patti, E. (2006). Capital structure and firm performance: A new approach to testing agency theory and an application to the banking industry. Journal of Banking and Finance, 30(4), 1065-1102. https://doi.org/10.1016/j.jbankfin.2005.05.015

Bouaziz, M. Z. (2014). Corporate Governance and Voluntary Financial Disclosure by Canadian Listed Firms. Management Review: An International Journal, 9(1), 44-69.

Broberg, P., Tagesson, T., \& Collin, S.-O. (2010). What explains variation in voluntary disclosure? A study of the annual reports of corporations listed on the Stockholm Stock Exchange. Journal of Management \& Governance, 14(4), 351-377. https://doi.org/10.1007/s10997-009-9104-y

Bursa Malaysia. (2006). Corporate Social Responsibility (CSR) framework for Malaysian public listed companies. $\begin{array}{lllll}\text { Retrieved } & 18 & \text { July } & 2015, & \text { from }\end{array}$ http://www.bursamalaysia.com/market/listed-companies/sustainability/frameworks/bursa-malaysias-csr-framew ork/

Carpenter, M. A., \& Westphal, J. D. (2001). The Strategic Context of External Network Ties: Examining the Impact of Director Appointments on Board Involvement in Strategic Decision Making. The Academy of Management Journal, 44(4), 639-660. https://doi.org/10.2307/3069408

Darus, F., Mad, S., Nejati, M., \& Yusoff, R. (2016). When quality matters! CSR disclosure and value creation. International Journal of Economics and Management, 10(S2), 285-302.

Darus, F., Yusoff, H., Mohamed, N., \& Nejati, M. (2016). Do Governance Structure and Financial Performance Matter in CSR Reporting?. International Journal of Economics and Management, 10(S2), 267-284.

De Villiers, C., Rinaldi, L., \& Unerman, J. (2014). Integrated Reporting: Insights, gaps and an agenda for future research. Accounting, Auditing \& Accountability Journal, 27(7), 1042-1067. https://doi.org/10.1108/AAAJ-06-2014-1736

Druckman, P. (2014). Integrated Reporting: A New Governance Tool. Corporate Board, 35(206), 6-10.

Eisenhardt, K. M. (1989). Agency Theory: An Assessment And Review. Academy of Management. The Academy of Management Review, 14(1), 57. https://doi.org/10.2307/258191

Freeman, R. E. (1994). The politics of stakeholder theory: Some future directions. Business Ethics Quarterly, 4(4), 409-421. https://doi.org/10.2307/3857340

Frias Aceituno, J. V., Rodriguez Ariza, L., \& Garcia Sanchez, I. M. (2013). The Role of the Board in the Dissemination of Integrated Corporate Social Reporting. Corporate Social Responsibility and Environmental Management, 20(4), 219-233. https://doi.org/10.1002/csr.1294

Frias Aceituno, J. V., Rodríguez Ariza, L., \& Garcia Sánchez, I. M. (2014). Explanatory Factors of Integrated Sustainability and Financial Reporting. Business Strategy and the Environment, 23(1), 56-72. https://doi.org/10.1002/bse.1765

Ghazali, N. A. M. (2007). Ownership structure and corporate social responsibility disclosure: some Malaysian evidence. Corporate Governance: The International Journal of Business in Society, 7(3), 251-266. https://doi.org/10.1108/14720700710756535

Greco, G. (2012). The management's reaction to new mandatory risk disclosure. Corporate Communications, 17(2), 113-137. https://doi.org/10.1108/13563281211220256

Hamdan, M. A. (2014). Embracing integrated reporting. New Straits Times (p. 1). Retrieved November 26, 2015, from https://www.nst.com.my/news/2015/09/embracing-integrated-reporting

Hamrouni, A., Miloudi, A., \& Benkraiem, R. (2015). Signaling Firm Performance Through Corporate Voluntary Disclosure. Journal of Applied Business Research, 31(2), 609-620. https://doi.org/10.19030/jabr.v31i2.9157

Haniffa, R. M., \& Cooke, T. E. (2002). Culture, Corporate Governance and Disclosure in Malaysian Corporations. Abacus, 38(3), 317-349. https://doi.org/10.1111/1467-6281.00112 
Hooks, J., \& van Staden, C. J. (2011). Evaluating environmental disclosures: The relationship between quality and extent measures. The British Accounting Review, 43(3), 200-213. https://doi.org/10.1016/j.bar.2011.06.005

Huafang, X., \& Jianguo, Y. (2007). Ownership structure, board composition and corporate voluntary disclosure: Evidence from listed companies in China. Managerial Auditing Journal, 22(6), 604-619. https://doi.org/10.1108/02686900710759406

Ibrahim, K. (2014). Firm Characteristics and Voluntary Segments Disclosure among the Largest Firms in Nigeria. International Journal of Trade, Economics and Finance, 5(4), 327-331. https://doi.org/10.7763/IJTEF.2014.V5.392

IIRC, I. I. R. C. (2013). The International Integrated Reporting Framework. International Integrated Reporting Council. Retrieved 11 June 2015, from http://integratedreporting.org/wp-content/uploads/2013/12/13-12-08-THE-INTERNATIONAL-IR-FRAMEWO RK-2-1.pdf

Janggu, T., Darus, F., Zain, M. M., \& Sawani, Y. (2014). Does Good Corporate Governance Lead to Better Sustainability Reporting? An Analysis Using Structural Equation Modeling. Procedia - Social and Behavioral Sciences, 145, 138-145. https://doi.org/10.1016/j.sbspro.2014.06.020

Jenkins, H., \& Yakovleva, N. (2006). Corporate social responsibility in the mining industry: Exploring trends in social and environmental disclosure. Journal of Cleaner Production, 14(3-4), 271-284. https://doi.org/10.1016/j.jclepro.2004.10.004

Jensen, J. C., \& Berg, N. (2012). Determinants of Traditional Sustainability Reporting Versus Integrated Reporting. An Institutionalist Approach. Business Strategy and the Environment, 21(5), 299-316. https://doi.org/10.1002/bse.740

Jensen, M. C., \& Meckling, W. (1976). Theory of the firm: Managerial behavior, agency costs and ownership structure. Journal of Financial Economics, 3(4), 305-360. https://doi.org/10.1016/0304-405X(76)90026-X

Kaur, A., \& Lodhia, S. K. (2014). The state of disclosures on stakeholder engagement in sustainability reporting in Australian local councils. Pacific Accounting Review, 26(1/2), 54-74. https://doi.org/10.1108/PAR-07-2013-0064

Khan, A., Muttakin, M. B., \& Siddiqui, J. (2013). Corporate Governance and Corporate Social Responsibility Disclosures: Evidence from an Emerging Economy. Journal of Business Ethics, 114(2), 207-223. https://doi.org/10.1007/s10551-012-1336-0

Knechel, W. R., \& Deumes, R. (2008). Economic incentives for voluntary reporting on internal risk management and control systems. Auditing, 27(1), 35-66. https://doi.org/10.2308/aud.2008.27.1.35

KPMG. (2011). Integrated reporting: Performance insights through better business reporting. KPMG. Retrieved 28 August 2015, from https://home.kpmg.com/ru/en/home/insights/2011/10/integrated-reporting-performance-insight-through-better-b usiness-reporting.html

Lan, Y., Wang, L., \& Zhang, X. (2013). Determinants and features of voluntary disclosure in the Chinese stock market. China Journal of Accounting Research, 6(4), 265-285. https://doi.org/10.1016/j.cjar.2013.04.001

Lodhia, S. (2015). Exploring the Transition to Integrated Reporting Through a Practice Lens: An Australian Customer Owned Bank Perspective. Journal of Business Ethics, 129(3), 585-598. https://doi.org/10.1007/s10551-014-2194-8

Menicucci, E. (2013). The Determinants of Forward-Looking Information in Management Commentary: Evidence from Italian Listed Companies. International Business Research, 6(5), 30-44. https://doi.org/10.5539/ibr.v6n5p30

Michelon, G., \& Parbonetti, A. (2012). The effect of corporate governance on sustainability disclosure. Journal of Management \& Governance, 16(3), 477-509. https://doi.org/10.1007/s10997-010-9160-3

Muhammad, S. D., \& Zafar, S. (2016). Determinants of Imports Demand Functions of Pakistan: An ARDL Bound Testing Approach. International Journal of Business, Economics and Management, 3(9), 113-121. https://doi.org/10.18488/journal.62/2016.3.9/62.9.113.121 
Mukherjee, S. (2017). The role of services in total productivity growth of indian manufacturing firms: A firm level analysis since 2000. Asian Journal of Economics and Empirical Research, 4(2), 121-131. https://doi.org/10.20448/journal.501.2017.42.121.131

Murshed, M. (2018). International Tourism Demand in Bangladesh: An ARDL Bounds Test Approach. Journal of Tourism Management Research, 5(1), 50-67. https://doi.org/10.18488/journal.31.2018.51.50.67

Neelam, S., Subhash, A., Mahesh, J., \& Anh Vu, H. (2015). Integrated reporting in South Africa: some initial evidence. Sustainability Accounting, Management and Policy Journal, 6(3), 397-424. https://doi.org/10.1108/SAMPJ-03-2014-0018

Nzimande, N., \& Padayachee, P. (2017). Evaluation of the current procurement planning process in a district municipality. International Journal of Public Policy and Administration Research, 4(1), 19-34. https://doi.org/10.18488/journal.74.2017.41.19.34

Obi, M. N., \& Okekeokosisi, J. (2018). Extent of Implementation of National Entrepreneurship Curriculum in Tertiary Institutions as Perceived by Educators. American Journal of Education and Learning, 3(2), 108-115. https://doi.org/10.20448/804.3.2.108.115

Obiekwe, O. (2018). Human Capital Development and Organizational Survival: A Theoretical Review. International Journal of Management and Sustainability, 7(4), 194-203. https://doi.org/10.18488/journal.11.2018.74.194.203

Okechukwu, O. C., \& Hyginus, O. O. (2017). National Security and Democratization in Nigeria: The Case of Insurgence. International Journal of Public Policy and Administration Research, 4(1), 12-18. https://doi.org/10.18488/journal.74.2017.41.12.18

Okon, E. O., \& Monday, O. I. (2017). Empirical and evidence-based investigation: External debt, poverty and economic growth nexus. International Journal of Applied Economics, Finance and Accounting, 1(1), 37-47. https://doi.org/10.33094/8.2017.11.37.47

Patten, D. M. (2002). Give or take on the internet: an examinationof the disclosure practices of insurance firm web innovators. Journal of Business Ethics, 36(3), 247-259. https://doi.org/10.1023/A:1014009229437

PwC. (2014). Where do Malaysian companies stack up in communicating performance and prospects? Integrated reporting helps companies build trust and create long term value. Press Room, pp. 1-43. Retrieved 28 July 2015, from http://www.pwc.com/my/en/press/140710-state-of-integrated-reporting-in-my-launch.html

Rachagan, S. (2010). Enhancing corporate governance in listed companies with concentrated shareholdings: A Malaysian perspective. Journal of Financial Crime, 17(4), 430-440. https://doi.org/10.1108/13590791011082788

Robertson, F. A., \& Samy, M. (2015). Factors affecting the diffusion of integrated reporting - a UK FTSE 100 perspective. Sustainability Accounting, Management and Policy Journal, 6(2), 190-223. https://doi.org/10.1108/SAMPJ-07-2014-0044

Ross, S. A. (1979). Disclosure regulation in financial markets: Implications of modern finance theory and signaling theory. Issues in Financial Regulation, 5, 177-202.

Rouf, M. (2011). The Financial Performance (Profitability) and Corporate Governance Disclosure in the Annual Reports of Listed Companies of Bangladesh. Journal of Economics and Business Research, 17(2), 103-117.

Sharif, M., \& Rashid, K. (2014). Corporate governance and corporate social responsibility (CSR) reporting: An empirical evidence from commercial banks (CB) of Pakistan. Quality \& Quantity, 48(5), 2501-2521. https://doi.org/10.1007/s11135-013-9903-8

Solomon, J., \& Maroun, W. (2012). Integrated reporting: the influence of King III on social, ethical and environmental reporting. ACCA, Lincoln's Inn Field, p. 1-55. Retrieved 28 December 2015, from http://www.accaglobal.com/ie/en/technical-activities/technical-resources-search/2012/august/integrated-reportin g-king-1ll.html

Star, T. (2015). IRSC - Integrated reporting game changer for corporations. Reterived November 26, 2015, from https://www.thestar.com.my/business/business-news/2015/09/07/irsc-integrated-reporting-game-changer-for-co rporations/ 
Sumiani, Y., Haslinda, Y., \& Lehman, G. (2007). Environmental reporting in a developing country: a case study on status and implementation in Malaysia. Journal of Cleaner Production, 15(10), 895-901. https://doi.org/10.1016/j.jclepro.2006.01.012

Ujunwa, A. (2012). Board characteristics and the financial performance of Nigerian quoted firms. Corporate Governance, 12(5), 656-674. https://doi.org/10.1108/14720701211275587

Warwick, S., \& Tuyana, D. (2015). Early assessments of the gap between integrated reporting and current corporate reportingnull. Meditari Accountancy Research, 23(1), 92-117. https://doi.org/10.1108/MEDAR-02-2014-0026

Wulf, I., Niemöller, J., \& Rentzsch, N. (2014). Development toward integrated reporting, and its impact on corporate governance: A two-dimensional approach to accounting with reference to the German two-tier system. Journal of Management Control, 25(2), 135-164. https://doi.org/10.1007/s00187-014-0200-z

\section{Appendices}

Descriptive statistics on the Integrated Reporting elements disclosure by items for 2014

\begin{tabular}{|c|c|c|c|c|c|c|c|}
\hline No & Items & $\mathbf{N}$ & Min & Max & Mean & $\begin{array}{l}\text { Std. } \\
\text { Dev. }\end{array}$ & $\begin{array}{l}\text { \% Mean Score } \\
(\text { mean/max })\end{array}$ \\
\hline & Organizational overview and business model: & & & & & & \\
\hline 1 & Mission and vision statements & 100 & 0 & 2 & 0.9 & 0.819 & $45 \%$ \\
\hline 2 & Value and culture & 100 & 0 & 2 & 1.06 & 0.915 & $53 \%$ \\
\hline 3 & Ownership and operating structure & 100 & 2 & 2 & 2 & 0.000 & $100 \%$ \\
\hline 4 & Principal activities, markets, products, services & 100 & 1 & 2 & 1.92 & 0.271 & $96 \%$ \\
\hline 5 & Reporting boundary & 100 & 0 & 0 & 0 & 0.000 & $0 \%$ \\
\hline \multirow[t]{2}{*}{6} & Key quantitative information & 100 & 2 & 2 & 2 & 0.000 & $100 \%$ \\
\hline & Operating context: & & & & & & \\
\hline \multirow[t]{5}{*}{1} & Legal & 100 & 0 & 1 & 0.55 & 0.497 & $55 \%$ \\
\hline & Commercial & 100 & 0 & 1 & 0.99 & 0.099 & $99 \%$ \\
\hline & Social & 100 & 1 & 1 & 1 & 0.00 & $100 \%$ \\
\hline & Environmental & 100 & 1 & 1 & 1 & 0.00 & $100 \%$ \\
\hline & Political & 100 & 0 & 1 & 0.08 & 0.271 & $8 \%$ \\
\hline 2 & Key risks and opportunities & 100 & 0 & 2 & 1.42 & 0.569 & $71 \%$ \\
\hline \multirow[t]{2}{*}{3} & $\begin{array}{l}\text { Material issues/determination, impact } \\
\text { creating/preserving value }\end{array}$ & 100 & 0 & 2 & 1.46 & 0.754 & $73 \%$ \\
\hline & Strategic objectives and strategies to achieve them: & & & & & & \\
\hline 1 & Short, medium, long term objectives & 100 & 0 & 2 & 1.35 & 0.536 & $67.5 \%$ \\
\hline 2 & Implementation plans (in relation to business model) & 100 & 0 & 2 & 1.74 & 0.461 & $87 \%$ \\
\hline 3 & Influence from/response to operating context & 100 & 0 & 1 & 0.88 & 0.325 & $88 \%$ \\
\hline 4 & Effect on key capitals/risk management arrangements & 100 & 0 & 2 & 1.38 & 0.629 & $69 \%$ \\
\hline \multirow[t]{2}{*}{5} & Stakeholder consultation in formulating strategies & 100 & 1 & 2 & 1.28 & 0.449 & $64 \%$ \\
\hline & Governance: & & & & & & \\
\hline 1 & $\begin{array}{l}\text { Leadership structure, diversity and skill set of those } \\
\text { charged with governance }\end{array}$ & 100 & 2 & 2 & 2 & 0.000 & $100 \%$ \\
\hline 2 & Actions taken to monitor strategic direction & 100 & 0 & 1 & 0.99 & 0.099 & $99 \%$ \\
\hline
\end{tabular}


\begin{tabular}{llllllll}
\hline 3 & Reflection of culture and ethical values in use of and & 100 & 0 & 2 & 1.61 & 0.551 & $80.5 \%$
\end{tabular} effect on the capitals, relationship with key stakeholders

\begin{tabular}{llllllll}
\hline 4 & Compensation policies and plans & 100 & 0 & 2 & 1.23 & 0.466 & $61.5 \%$ \\
\hline 5 & Oversight over the IR process & 100 & 0 & 2 & 0.06 & 0.276 & $3 \%$ \\
\hline & Performance: & & & & & & \\
\hline 1 & KPIs & 100 & 0 & 2 & 1.79 & 0.475 & $89.5 \%$ \\
\hline 2 & KRIs & 100 & 0 & 1 & 0.16 & 0.367 & $16 \%$ \\
\hline 3 & The organization's effect on the capitals & 100 & 1 & 2 & 1.29 & 0.454 & $64.5 \%$ \\
\hline 4 & State of key stakeholder relationships & 100 & 1 & 2 & 1.32 & 0.466 & $66 \%$ \\
\hline 5 & Significant external factors & 100 & 0 & 2 & 1.38 & 0.704 & $69 \%$ \\
\hline 6 & Comparison of actual results vs target & 100 & 0 & 1 & 0.11 & 0.313 & $11 \%$ \\
\hline 7 & Comparison against regional/industry benchmarks & 100 & 0 & 1 & 0.13 & 0.336 & $13 \%$ \\
\hline 8 & Management's expectations & 100 & 0 & 1 & 0.97 & 0.171 & $97 \%$ \\
\hline 9 & Uncertainties & 100 & 0 & 1 & 0.58 & 0.494 & $58 \%$ \\
\hline 10 & Real risks with extreme consequences & 100 & 0 & 1 & 0.28 & 0.449 & $28 \%$ \\
\hline 11 & Potential implications & 100 & 0 & 1 & 0.68 & 0.466 & $68 \%$ \\
\hline & Assurance: & & & & & & \\
\hline 1 & Mandatory audit & 100 & 1 & 1 & 1 & 0.00 & $100 \%$ \\
\hline 2 & Review & 100 & 1 & 1 & 1 & 0.00 & $100 \%$ \\
\hline 3 & Internal Audit & 100 & 1 & 1 & 1 & 0.00 & $100 \%$ \\
\hline & & & & & \\
\hline
\end{tabular}

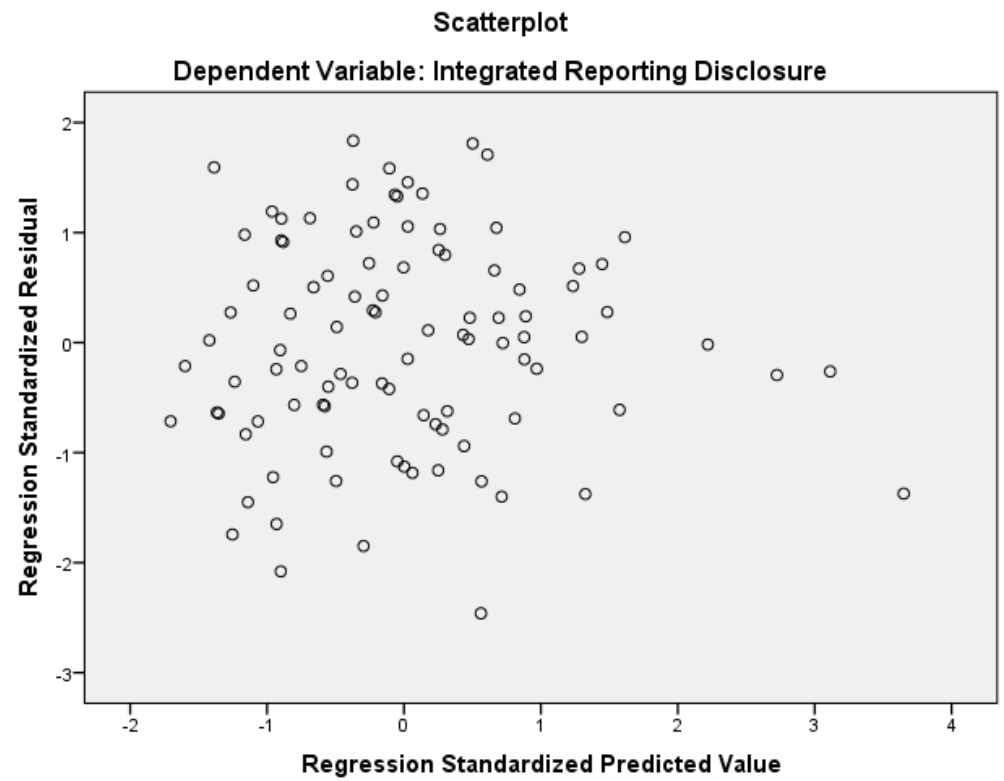

